\title{
Mechanical and Durability Properties of Concrete Made with Used Foundry Sand as Fine Aggregate
}

\author{
G. Ganesh Prabhu, ${ }^{1}$ Jin Wook Bang, ${ }^{1}$ Byung Jae Lee, ${ }^{2}$ \\ Jung Hwan Hyun, ${ }^{1}$ and Yun Yong Kim ${ }^{1}$ \\ ${ }^{1}$ Department of Civil Engineering, Chungnam National University, Daejeon 305-764, Republic of Korea \\ ${ }^{2}$ R๘D Center, JNTINC Co. Ltd., Hwaseong, Republic of Korea
}

Correspondence should be addressed to Yun Yong Kim; yunkim@cnu.ac.kr

Received 8 December 2014; Accepted 27 January 2015

Academic Editor: Antônio G. de Lima

Copyright (C) 2015 G. Ganesh Prabhu et al. This is an open access article distributed under the Creative Commons Attribution License, which permits unrestricted use, distribution, and reproduction in any medium, provided the original work is properly cited.

\begin{abstract}
In recent years, the construction industry has been faced with a decline in the availability of natural sand due to the growth of the industry. On the other hand, the metal casting industries are being forced to find ways to safely dispose of waste foundry sand (FS). With the aim of resolving both of these issues, an investigation was carried out on the reuse of waste FS as an alternative material to natural sand in concrete production, satisfied with relevant international standards. The physical and chemical properties of the FS were addressed. The influence of FS on the behaviour of concrete was evaluated through strength and durability properties. The test results revealed that compared to the concrete mixtures with a substitution rate of $30 \%$, the control mixture had a strength value that was only $6.3 \%$ higher, and this enhancement is not particularly high. In a similar manner, the durability properties of the concrete mixtures containing FS up to $30 \%$ were relatively close to those of control mixture. From the test results, it is suggested that FS with a substitution rate of up to $30 \%$ can be effectively used in concrete production without affecting the strength and durability properties of the concrete.
\end{abstract}

\section{Introduction}

The rapid advance of globalization and the growth in the population has resulted in a growth in building construction that has consequently led to a higher demand for construction materials. River sand is one of the main ingredients used as a fine aggregate in concrete production. A rising demand for construction material has led to the overexploitation of river sand, and this overexploitation has led to harmful consequences like increase in river bed depth, lowering of the water table, and intrusion of salinity into the river. In addition, the restriction in the extraction of sand by government organizations has increased the price of sand, severely affecting the stability of the construction industry [1]. For this reason, finding an alternative material to sand has become vital. Over the last several decades, an enormous amount of research has been carried on the use of industrial waste, including granite and marble waste [2-7], tire waste [8], palm oil ash [9], timber waste [10], and also marine sand [11] as a substitute/replacement material for fine aggregate. From the research outcomes, it was suggested that the substitution of industrial waste as an alternative material in concrete making could improve the structural properties of concrete and promote sustainable concrete development. Foundry sand (FS) is a high silica content sand material which is a by-product from the metal alloys casting industries [12]. In foundries, superior silica sands are bonded with clay or chemicals and used for the material molding and casting process. Foundries recycle the sand as many times as possible, and when the sand is no longer recyclable, then it is disposed of; this is called foundry sand [13]. About $15 \%$ of the sand utilized in casting production is ultimately disposed of by the foundry industry, amounting to millions of tons. In India, many foundry industries are dumping this waste in nearby vacant areas, which is creating an environmental problem. In Coimbatore, Tamilnadu, India, many residential areas 
are established over landfills, which are basically composed of FS from ferrous and nonferrous industries. Landfill is an incorrect option, because the embodied energy in FS is not used and will create soil contamination [14].

Over the last several decades, FS has been reused as a subgrade material [15] in highway and soil stabilization application [16]. However, the waste that is reutilized in this way very is negligible, and the practice presents the risk of leaching intrusion. Very recently, research has been carried out on the reutilization of FS as substitute material in concrete and concrete related products. A marginal increase in the strength properties can be achieved by the inclusion of UFS as partial replacement for fine aggregate in concrete making [13]. The replacement of $10 \%$ aggregates with waste foundry sand was suitable for asphalt concrete mixtures, and the substitution did not significantly affect the environment around the deposition [17]. FS is a viable means of producing economical self-compacting concrete (SCC) by using FS substitution; however, further research is needed to develop the optimum FS proportion [18]. The substitution of foundry sand in concrete reduces the voids in concrete and has helped to spread the C-S-H gel widely in the concrete [19]. The Inclusion of FS as a sand replacement significantly improved the abrasion resistance of concrete at all ages because of the formation of a denser matrix [20]. FS can be effectively utilized in making good quality RMC as a partial replacement for fine aggregates with no adverse mechanical, environmental, and microstructural impacts; however, the replacement should not exceed 20\% [21].

It can be understood that a great deal of research has been carried out on the reuse of FS in civil engineering application. However, limited research has been focused on the use of FS in concrete production, and more research is also needed to develop the most favorable replacement of FS in concrete production. With this aim, the main objective of this experimental investigation is to examine the potential reuse of FS obtained from an aluminium casting industry, Coimbatore, in Tamilnadu, India, as a replacement for fine aggregate in concrete production, at different substitution rates. The effect of FS substitution on the mechanical properties of concrete was examined. In addition, the influence of FS on the durability properties of concrete was also evaluated in order to ensure the reliability of its usage in aggressive environments. Based on the results of the mechanical and durability tests, the most favorable proportion of FS in concrete production was established.

\section{Experimental Program}

2.1. Materials. Locally available ordinary/commercial Portland cement was used in this study as a binding material. The specific gravity of the cement was tested according to IS 8112:2013 [22] and the value obtained was about 3.14. The chemical properties of the cement were tested according to IS 4032:1985 [23], and the results were summarized in Table 2. The river sand passing through $4.75 \mathrm{~mm}$ was used as fine aggregate. Locally available $20 \mathrm{~mm}$ size blue metal jelly was used as a coarse aggregate. The specific gravity [24] of the sand and the coarse aggregate was about 2.48 and 2.67 , respectively.

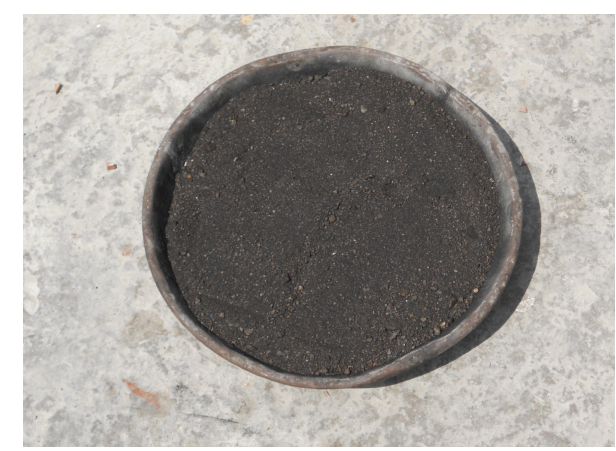

FIGURE 1: Foundry industry dumping solid waste along Madurai to Coimbatore highway in Tamilnadu, India, and foundry sand used in this study.

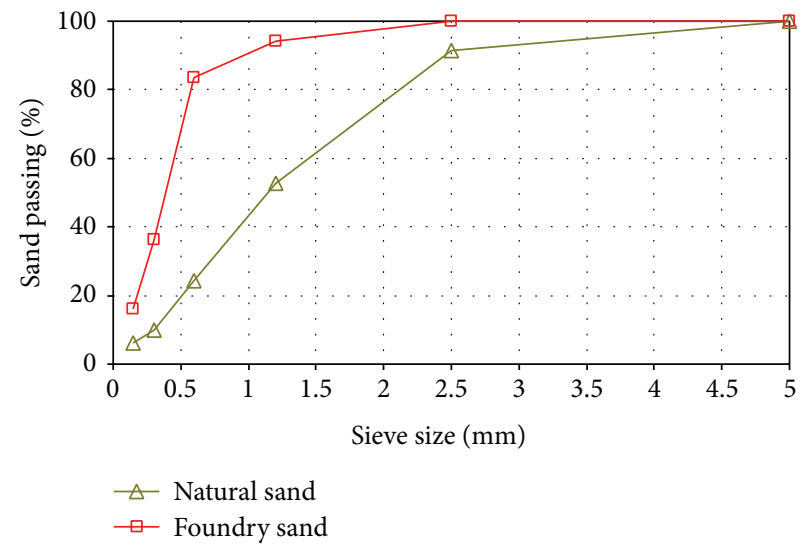

FIGURE 2: Sieve analysis results of natural and foundry sand.

According to IS 2386(1):1963 [25], sieve analysis was carried out on both fine and coarse aggregate. Foundry sand (FS) obtained from an aluminium casting industry, Coimbatore, in Tamilnadu, India, was used in this study and the FS is shown in Figure 1. It is a green sand (clay sand); clay was used as a binder material. The physical and chemical properties of the FS were tested according to Indian standards and they were listed in Tables 1 and 2, respectively. The specific gravity and density [24] of the FS were about 2.24 and $1576 \mathrm{~kg} / \mathrm{m}^{3}$, respectively. The water absorption [26] of the FS was about $1.13 \%$, which is higher than that of normal sand due to the presence of ashes and wood particles. Sieve analysis was carried out to understand the grain size distribution of the FS (see Figure 2), and it was observed that $8 \%$ of FS were less than $75 \mu \mathrm{m}$, which show that the FS is fineness material. The chemical properties of the FS were tested according to IS 4032:1985 [23], and the results obtained showed that FS contains about $87.48 \%$ silica $\left(\mathrm{SiO}_{2}\right)$ and $4.93 \%$ alumina $\left(\mathrm{Al}_{2} \mathrm{O}_{3}\right)$. The results of the chemical analysis indicated that FS is a very suitable material for concrete production.

2.2. Concrete. Concrete mix proportions were designed to achieve the strength of M25, according to IS 10262:2009 [27]. The concrete mix proportion was $1: 1.53: 2.86$. A constant water to cement ratio (W/C) was followed for all mixtures, 
TABLE 1: Physical property of the foundry sand (FS).

\begin{tabular}{lc}
\hline Property & Foundry sand \\
\hline Specific gravity & 2.24 \\
Density $\left(\mathrm{kg} / \mathrm{m}^{3}\right)$ & 1576 \\
Water absorption $(\%)$ & 1.13 \\
Materials finer than $75 \mu \mathrm{m}$ & 8 \\
\hline
\end{tabular}

TABLE 2: Chemical property of the cement and foundry sand (FS).

\begin{tabular}{lcc}
\hline Chemical composition & $\begin{array}{c}\text { Cement } \\
\text { \% by mass }\end{array}$ & $\begin{array}{c}\text { FS } \\
\text { \% by mass }\end{array}$ \\
\hline Lime (as $\mathrm{CaO})$ & $62-63$ & 0.22 \\
Soluble silica $\left(\mathrm{as} \mathrm{SiO}_{2}\right)$ & $20-21$ & 87.48 \\
Alumina $\left(\mathrm{as}_{2} \mathrm{O}_{3}\right)$ & $5.2-5.6$ & 4.93 \\
Iron oxide $\left(\mathrm{as} \mathrm{Fe}_{2} \mathrm{O}_{3}\right)$ & $4.4-4.8$ & 1.31 \\
Magnesia $($ as $\mathrm{MgO})$ & $0.5-0.7$ & 0.18 \\
Sulphur calculated as & $2.4-2.8$ & 0.07 \\
sulphuric anhydride (as $\left.\mathrm{SO}_{3}\right)$ & $1.5-2.5$ & 5.81 \\
Loss on ignition $(\mathrm{LOI})$ &
\end{tabular}

and the value was about 0.44 . Of the six mixtures, five mixtures were prepared by replacing $10 \%, 20 \%, 30 \%, 40 \%$, and $50 \%$ of natural sand with FS, and the one remaining mixture was a control mixture (CM) that did not use FS. The detailed formulation of the proportions of six mixtures was given in Table 3.

2.3. Specimen Preparation. The concrete mixtures were prepared with and without FS substitution. The FS substitution rate was varied between $10 \%$ to $50 \%$, in increments of $10 \%$. FS was washed with fresh water more than four times before it was used in the concrete to remove the ashes and clay particles. Then it was dried in atmospheric sunlight for the duration of two days and then used in concrete mixtures. For all mixtures, the aggregates such as cement, natural sand, coarse aggregate, and FS were weighed in a dry condition and were mixed together in a laboratory batch mixer in order to avoid aggregate and water loss. The properties of the fresh concrete, such as its workability, were measured by the slump cone test. To determine the compressive strength and tensile strength of the concrete, cubes and cylinders with a size of $150 \mathrm{~mm} \times 150 \mathrm{~mm} \times 150 \mathrm{~mm}$ and $150 \mathrm{~mm} \times$ $300 \mathrm{~mm}$ were prepared. Beams having a size of $100 \mathrm{~mm} \times$ $100 \mathrm{~mm} \times 500 \mathrm{~mm}$ were also prepared to evaluate the flexural strength of the concrete. All the specimens were filled with concrete in three layers, and each layer of the concrete was effectively compacted by table vibrator [28]. After casting all specimens, the specimens were covered with a plastic sheet in order to avoid moisture loss. After that, specimens were kept at room temperature for $24 \mathrm{hrs}$ and thereafter were demoulded and transferred to the curing tank until their testing dates. After the required curing days, the cubes were tested in a compression testing machine (CTM) having a capacity of $2000 \mathrm{kN}$ at the ages of 7, 28, 90, and 180 days. The cylinders and beams were tested in the CTM and flexural testing machine, respectively, at the ages of 28, 90, and 180 days to evaluate the tensile and flexural strength of the concrete [28]. All specimens were tested according to the Indian standards [29]. According to the procedure described in ASTM C1202-97 [30], the chloride permeability test was conducted on all concrete mixtures, and resistance to the penetration of chloride ions was measured by determining the electrical conductance of concrete. A concrete disc having $102 \mathrm{~mm}$ diameter and $51 \mathrm{~mm}$ thickness was prepared and allowed to cure until the testing dates. Afterwards, both ends of the disc were sealed with cell, one of which was filled with $3 \% \mathrm{NaCl}$ solution, while the other was filled with $0.3 \mathrm{~N} \mathrm{NaOH}$ solutions. A potential difference of $60 \mathrm{~V}$ was maintained across the two cells and the amount of charge passed to the specimen was monitored for the duration of $6 \mathrm{hrs}$. The amount of chloride penetration was measured in terms of Coulombs [11]. According to IS 3085:1965 [31], the water permeability of the concrete was determined and the concrete permeability test apparatus was used in this study to determine the water permeability. By measuring the water volume that passes through the specimen under constant air pressure $10 \mathrm{~kg} / \mathrm{cm}^{2}$, the water permeability of the concrete was obtained. Concrete cylinders having a size of $150 \mathrm{~mm} \times$ $300 \mathrm{~mm}$ were prepared for the carbonation test. After curing days, all the specimens were air cured for the duration of 90 days and 180 days and then they were split. The split surface of the concrete was thoroughly cleaned and the phenolphthalein indicator was uniformly applied along the entire length using a brush. The average depth was measured at three points to the nearest $1 \mathrm{~mm}$, from the external surface to the colorless phenolphthalein region [11]. The electrical resistivity of the concrete was determined using a concrete electrical resistivity meter, under saturated condition. Concrete cubes having a size of $150 \mathrm{~mm} \times 150 \mathrm{~mm} \times 150 \mathrm{~mm}$ were prepared in all mixtures for sulphate resistance test. The cubes were immersed in a solution containing 7.5\% $\mathrm{NaSO}_{4}$ and $\mathrm{MgSO}_{4}$ by weight of water, for the duration of 180 days and 365 days. The sulphate resistance of the concrete mixtures was evaluated by measuring the compressive strength of the immersed cubes at the age of 180 days and 365 days. To discuss the mixtures easily, names were given to the mixtures, such as CM, FS $10 \%$, FS $20 \%$, FS $30 \%$, FS $40 \%$, and FS $50 \%$. For example, the name FS $20 \%$ indicated that the concrete mixture contained $20 \%$ foundry sand.

\section{Result and Discussion}

3.1. Fresh Concrete Properties. The workability of the concrete was measured through the slump cone test apparatus at times ranging from immediate after mixing, after 30 minutes and after 60 minutes. The results revealed that the substitution of FS decreases the workability of the concrete; furthermore, an increase in the substitution rate decreases the workability of the concrete further [28], as shown in Figure 3. However, close observation of Figure 3 shows that the influence of FS on the workability of the concrete was profound when the substitution rate was beyond $30 \%$, and, in addition, the slump value of the mixtures FS $30 \%$ was relatively equal to the $\mathrm{CM}$. The decrease in the workability of the concrete with 
TABLE 3: Different concrete mixtures and workability.

\begin{tabular}{lccccccc}
\hline Mixture & $\begin{array}{c}\text { Water } \\
\left(\mathrm{kg} / \mathrm{m}^{3}\right)\end{array}$ & $\begin{array}{c}\text { Cement } \\
\left(\mathrm{kg} / \mathrm{m}^{3}\right)\end{array}$ & $\begin{array}{c}\text { Sand } \\
\left(\mathrm{kg} / \mathrm{m}^{3}\right)\end{array}$ & $\begin{array}{c}\text { Coarse aggregate } \\
\left(\mathrm{kg} / \mathrm{m}^{3}\right)\end{array}$ & $\begin{array}{c}\text { Foundry sand (FS) } \\
\left(\mathrm{kg} / \mathrm{m}^{3}\right)\end{array}$ & $\begin{array}{c}\text { Slump values (mm) } \\
\text { Imm. after mixing }\end{array}$ & $\begin{array}{c}\text { After 30 min } \\
\text { After 60 min }\end{array}$ \\
\hline Control mixture (CM) & 177 & 402.37 & 616.52 & 1152.25 & 0 & 115 & 96 \\
FS 10\% & 177 & 402.37 & 554.86 & 1152.25 & 61.652 & 112 & 91 \\
FS 20\% & 177 & 402.37 & 493.26 & 1152.25 & 123.304 & 101 & 77 \\
FS 30\% & 177 & 402.37 & 431.567 & 1152.25 & 184.96 & 92 & 24 \\
FS 40\% & 177 & 402.37 & 369.91 & 1152.25 & 246.61 & 74 & 7 \\
FS 50\% & 177 & 402.37 & 308.26 & 1152.25 & 308.26 & 63 & 39 \\
\hline
\end{tabular}

TABLE 4: Experimental and computed compressive strength.

\begin{tabular}{|c|c|c|c|c|c|c|}
\hline \multirow{2}{*}{ Mixtures designation } & \multicolumn{4}{|c|}{ Experimental compressive strength $\left(\mathrm{N} / \mathrm{mm}^{2}\right)$} & \multicolumn{2}{|c|}{ Compressive strength computed using ACI 209 (Type 1) $\left(\mathrm{N} / \mathrm{mm}^{2}\right)$} \\
\hline & 7 days & 28 days & 90 days & 180 days & 90 days & 180 days \\
\hline $\mathrm{CM}$ & 21.54 & 33.14 & 37.24 & 37.29 & 37.05 & 37.99 \\
\hline FS $10 \%$ & 21.16 & 33.24 & 36.98 & 36.55 & 37.16 & 38.11 \\
\hline FS $20 \%$ & 21.17 & 32.58 & 36.17 & 36.12 & 36.42 & 37.35 \\
\hline FS $30 \%$ & 20.30 & 31.24 & 34.01 & 34.53 & 34.93 & 35.82 \\
\hline FS $40 \%$ & 19.41 & 29.48 & 31.83 & 31.43 & 32.96 & 33.80 \\
\hline FS 50\% & 16.38 & 25.23 & 27.54 & 27.98 & 28.17 & 28.89 \\
\hline
\end{tabular}

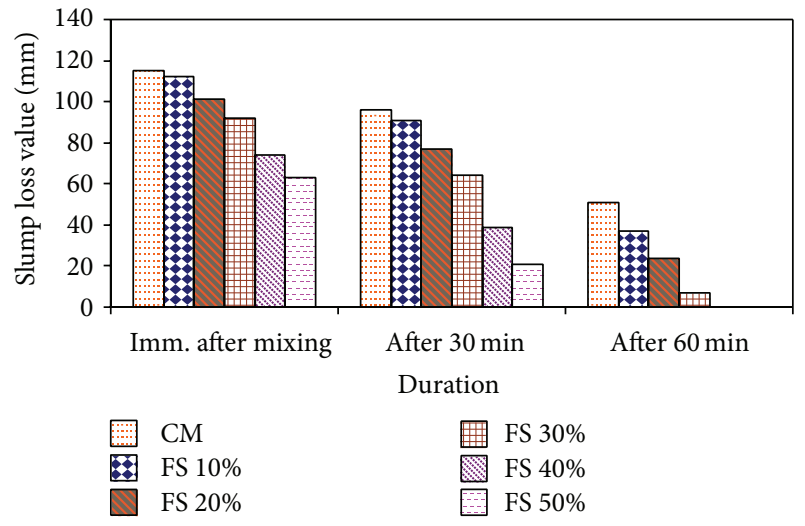

FIGURE 3: Workability of all concrete mixtures: comparision.

the substitution of FS may be attributed to the fineness and high water absorption properties of the FS. The fineness and high water absorption of the FS increases the water demand of the concrete by water absorption, resulting in decreased workability. The workability of the concrete was decreased as time elapsed; however, the slump loss of FS mixtures was high when compared to the CM. The fineness of the FS increases the surface of hydration products, leading to greater water absorption. From the observation, it was observed that modification of the water content should be applied to the mixtures based on the fineness of the substitution material [28].

\subsection{Mechanical Properties}

3.2.1. Compressive Strength. The compressive strength of all mixtures was obtained at ages of 7, 28, 90, and 180 days, and the values are summarized in Table 4 and presented in Figure 4.

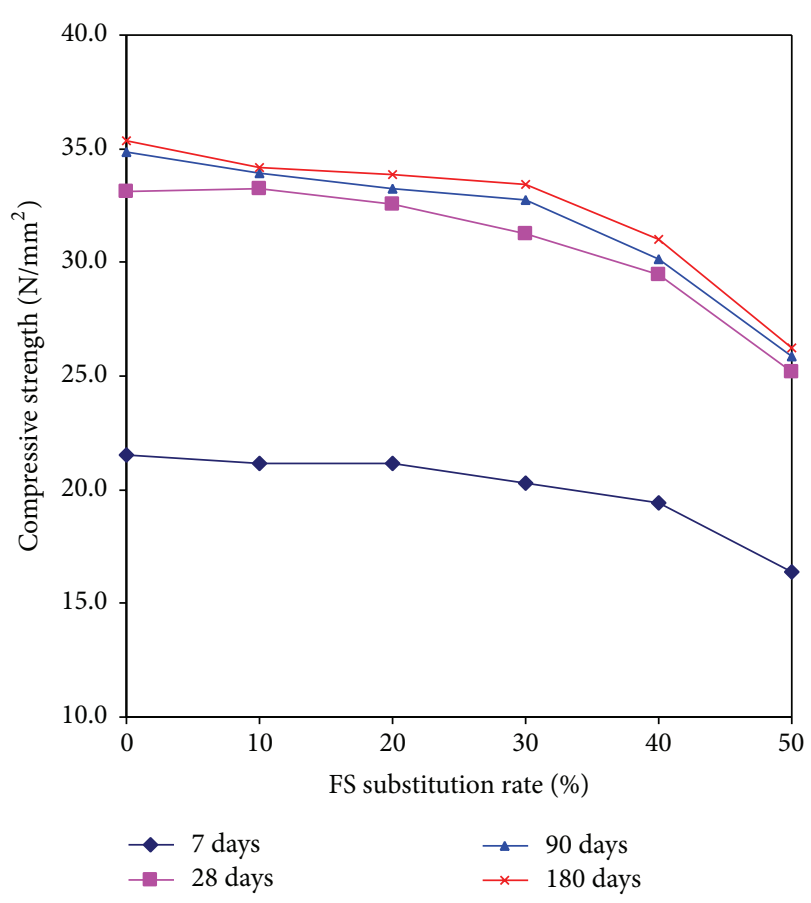

FIGURE 4: Comparison of compressive strength value of all mixtures at different ages.

The main objective of this research is to utilize FS as a substitute material in concrete production and not to enhance the strength properties of the concrete. As expected, it was observed that even though no improvement in strength was observed in FS concrete, the compressive strength of the concrete mixture FS 30\% was probably equal to the strength value of the control concrete $(\mathrm{CM})$. Compared to mixture 
FS 30\%, control mixture has shown $5.7 \%$ higher compressive strength at the age of 28 days; in addition the similar difference was observed at the ages of 180 and 365 days. However, mixtures FS $40 \%$ and FS 50\% were shown to have lower strength compared to the CM mixture at the age of 28 days, and, furthermore, showed a poor enhancement in strength upon aging when compared to the other mixtures. The certain properties of FS such as fineness and high water absorption decrease the compressive strength of the concrete. The fineness and high water absorption of the FS creates water demand in the concrete, causing poor workability and leading to a decrease in the compaction of the concrete, resulting in the formation of higher number of small pores close to the aggregate surfaces. The other possible factor is that the presence of clay, sawdust, and wood flour results in a reduction of the specific density of the material and also decreases the density of the concrete by creating air voids in the concrete [28]. The compressive strength of the concrete upon aging was determined by using (1), recommended by ACI 209 (ASTM Type 1) [32]. Consider the following:

$$
f_{\mathrm{cm}}(t)=f_{\mathrm{c} 28}\left(\frac{t}{4+0.85 t}\right) \text {, }
$$

where $f_{\mathrm{cm}}(t)$ is the mean compressive strength at the age of $t$ days, $f_{\mathrm{c} 28}$ is the mean compressive strength at 28 days, and $t$ is the age of the concrete in days. The calculated compressive strength values of the concrete are listed in Table 4 . The correlation made between the measured and calculated compressive strength of the linear regression line was shown to be strong as shown in Figure 5.

3.2.2. Flexural and Split Tensile Strength. The flexural and split tensile strength of all concrete mixtures were measured at the ages of 28,90 , and 180 days. Like compressive strength, up to a substitution rate of $30 \%$ the flexural and tensile strength of the concrete mixtures was relatively equal to the strength value of the CM. For instance, the flexural strength of the mixtures FS $30 \%$ was about $3.879 \mathrm{~N} / \mathrm{mm}^{2}$, whereas the control mixtures achieved the strength of about $4.087 \mathrm{~N} / \mathrm{mm}^{2}$, which is only $3 \%$ higher than that of mixtures FS $30 \%$. At the age of 28 days, compared to FS $10 \%$, FS $20 \%$, and FS $30 \%$ mixtures, mixture CM showed tensile strength that was $4.53 \%, 6.03 \%$, and $7.08 \%$, respectively, higher and this difference in strength is not relatively high. A similar difference was observed in both the flexural and split tensile strength of the concrete at the ages of 180 and 365 days. The flexural and tensile strength of the mixtures with the substitution rate up to $30 \%$ was increased upon aging; however, this behaviour was not observed in the FS $40 \%$ and FS $50 \%$. This is a result of the increase in the continuous porous system, resulting in a poor denser matrix due to the fineness and the presence of dust particles of the FS [28]. Compared to FS $40 \%$ and FS 50\% mixtures, the mixture CM showed a tensile strength of $16.38 \%$ and $19.32 \%$, respectively, higher. Based on (2) suggested in IS 456:2000 [33], the flexural strength of the concrete was estimated from the compressive strength obtained. Consider the following:

$$
f_{\mathrm{ft}}=0.70 x \sqrt{f_{\mathrm{ck}}}
$$

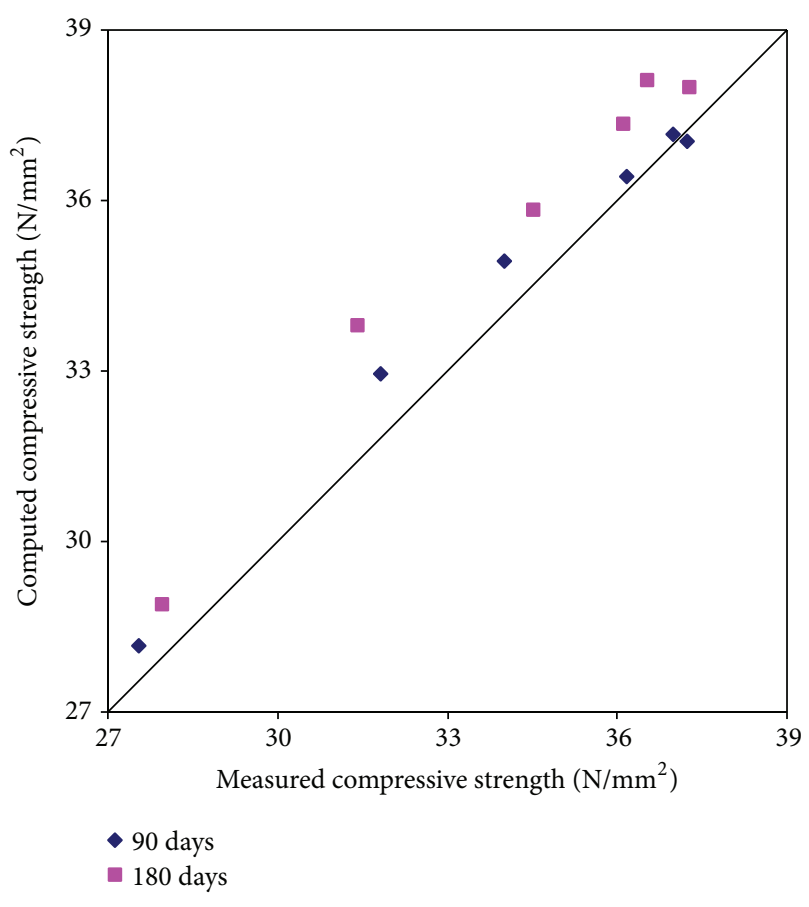

FIGURE 5: Measured and computed compressive strength value of all concrete mixtures: correlation.

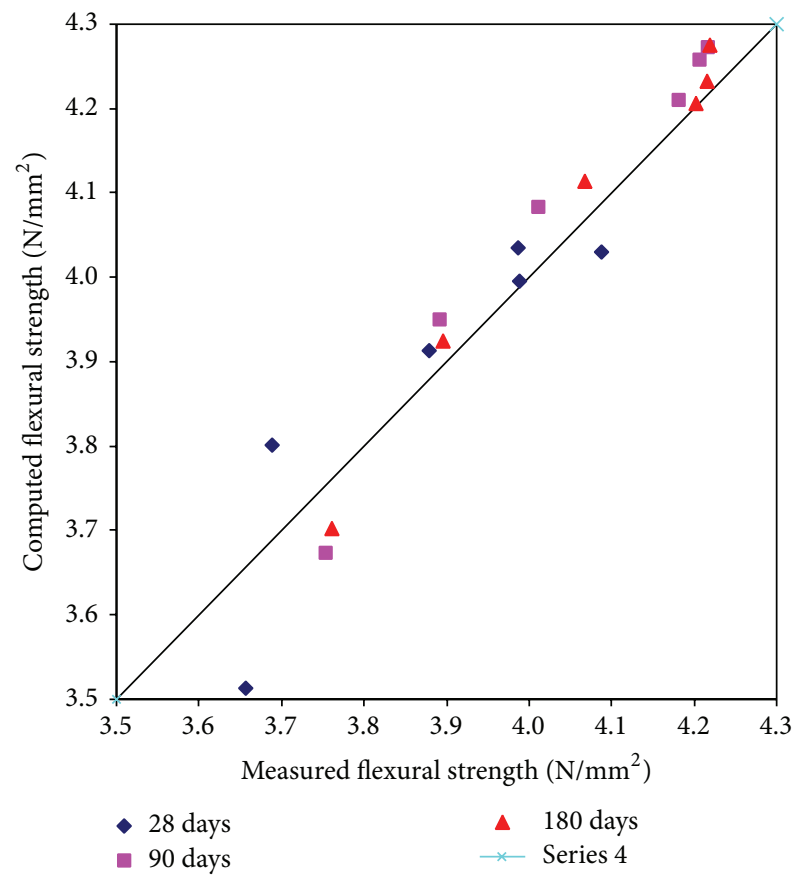

FIGURE 6: Measured and computed flexural strength value of all concrete mixtures: correlation.

where $f_{\mathrm{ft}}$ is the flexural strength of the concrete and $f_{\mathrm{ck}}$ is the compressive strength of the concrete. The correlation between the measured and computed flexural strength was quite strong, as shown in Figure 6, and the mean $R^{2}$ value was 0.9799 . The split tensile strength of the concrete was evaluated from the obtained flexural strength value based on 


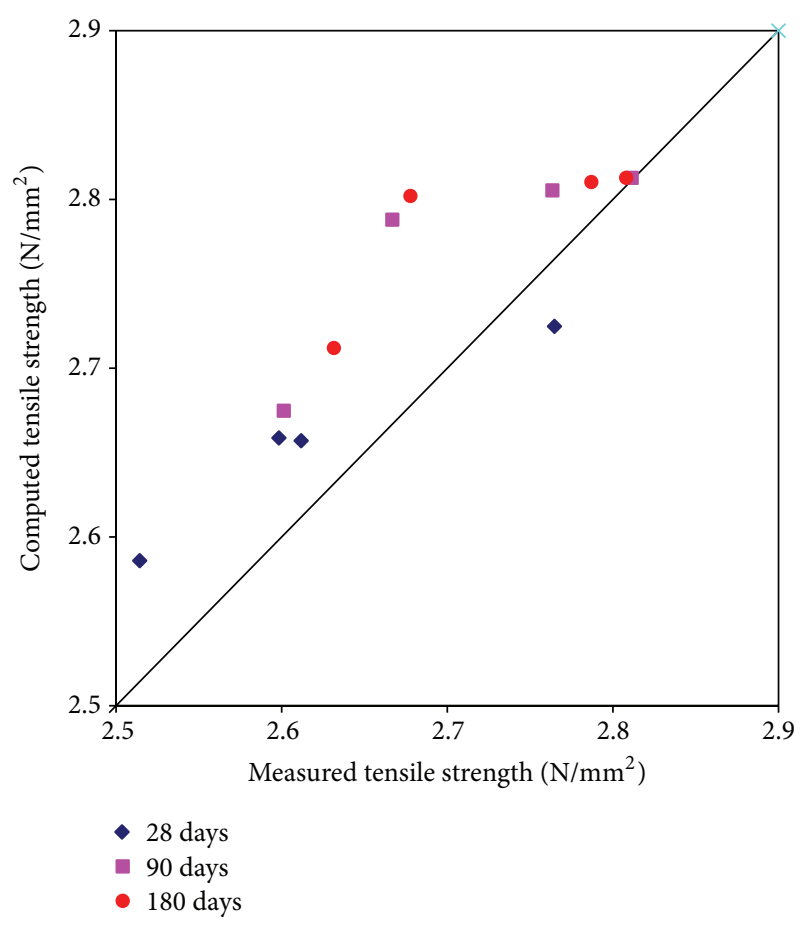

FIGURE 7: Measured and computed split tensile strength value of all concrete mixtures: correlation.

(3), recommended in the CEB-FIP Model Code:1990 [34]. Consider the following:

$$
f_{\mathrm{st}}=f_{\mathrm{fl}} x \frac{2.0\left(h / h_{0}\right)^{0.7}}{1+2.0\left(h / h_{0}\right)^{0.7}}
$$

where $h$ is the depth of the beam in $\mathrm{mm}$ and $h_{0}$ has the value of $100 \mathrm{~mm}$. The strengths obtained are expressed in $\mathrm{N} / \mathrm{mm}^{2}$. The correlation between the measured tensile strength and the tensile strength calculated using linear regression analysis was strong, as shown in Figure 7. Based on the experimental split tensile strength obtained, the relation between the compressive strength and tensile strength was found and expressed in the following:

$$
f_{\mathrm{st}}=0.85\left(f_{\mathrm{ck}}\right)^{0.315},
$$

where $f_{\text {st }}$ is the split tensile strength of the concrete and $f_{\text {ck }}$ is the compressive strength of the concrete.

3.2.3. Elastic Modulus. The dynamic elastic modulus of the concrete was determined using (5), recommended in 13311(1):1992 [35] and IS 452:2000 [33], from the ultrasonic pulse velocity (UPV) and compressive strength values obtained at the age of 28, 90, and 180 days. Consider the following:

$$
\begin{gathered}
E=\frac{\rho(1+\mu)(1-2 \mu)}{1-\mu} V^{2}, \\
E=5000 x \sqrt{f_{\mathrm{ck}}},
\end{gathered}
$$

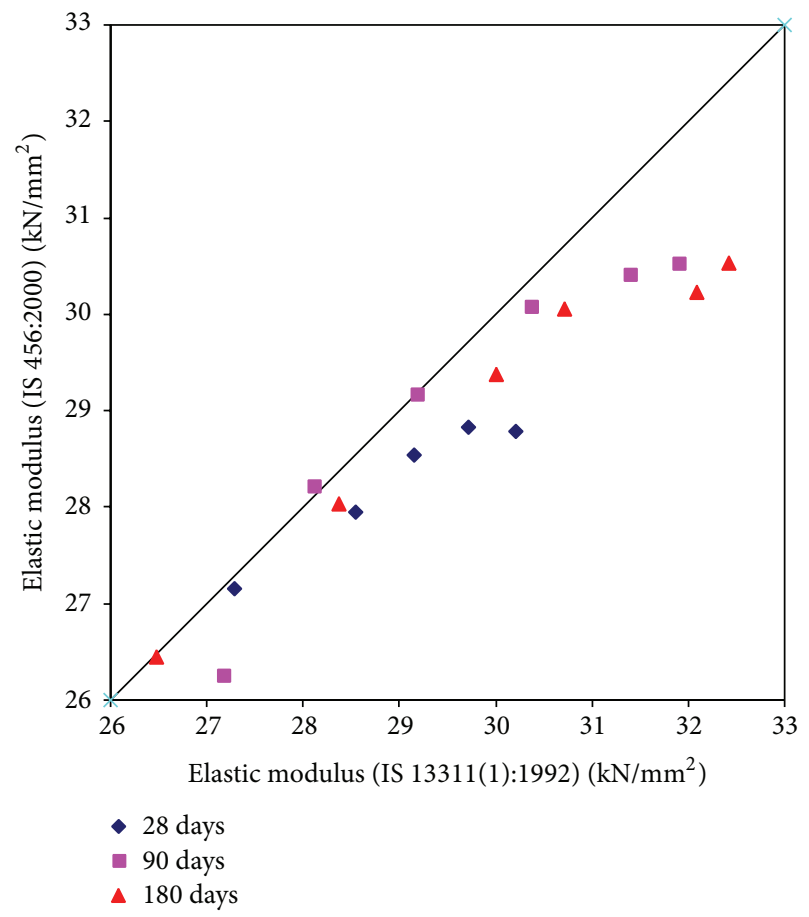

FIGURE 8: Relation between elastic modulus calculated using IS 13311(1):1992 and IS 456:2000.

where $E$ is the dynamic Young's modulus of elasticity (Mpa) and $f_{\mathrm{ck}}$ is the compressive strength of concrete, $\rho$ is the density of concrete in $\mathrm{kg} / \mathrm{m}^{3}, V$ is the pulse velocity in $\mathrm{m} / \mathrm{sec}$ ond, and $\mu$ is the dynamic poissons ratio of the concrete. The difference between the calculated elastic modulus values was not great and the values were relatively close, as shown in Figure 8.

\subsection{Durability Properties}

3.3.1. Rapid Chloride Ion Penetration (RCPT) Test. The service life of reinforced concrete structures generally depends upon the capacity of the concrete to resist chloride ion penetration. RCPT test was thus conducted on all mixtures at the ages of 180 and 365 days, according to the procedure described in ASTM C1202-97 [30], and the results were compared with the penetration limits suggested in ASTM C120297 [30]. The resistance of all mixtures to chloride penetration is shown in Figure 9 and listed in Table 5. From Figure 9, it can be understood that the substitution of FS in concrete increases the chloride penetration value of the concrete, and the increase in penetration was directly proportional to the FS substitution rate. However, the penetration values of the mixtures with a substitution rate of up to $30 \%$ was moderately equal to the penetration value of the CM. The penetration value of the FS 30\% was 621 coulombs at the age of 180 days, whereas the control mixture achieved a penetration value of 420 coulombs, which is only $32.36 \%$ lower than that of mixture FS $30 \%$. However the penetration value of the FS $30 \%$ is much lower than the maximum value recommended in ASTM C1202-97 [30]. The same difference 
TABLE 5: RCPT, permeability coefficient, and carbonation depth values of all concrete mixtures.

\begin{tabular}{lcccccccc}
\hline Mixtures designation & \multicolumn{2}{c}{$\begin{array}{c}\text { RCPT values } \\
\text { (Coulombs) }\end{array}$} & \multicolumn{2}{c}{$\begin{array}{c}\text { Permeability coefficient } \\
\left(10^{-12} \mathrm{~m} / \mathrm{s}\right)\end{array}$} & \multicolumn{2}{c}{$\begin{array}{c}\text { Carbonation depth } \\
(\mathrm{mm})\end{array}$} & \multicolumn{2}{c}{$\begin{array}{c}\text { Carbonation coefficient } \\
\left(\mathrm{mm} / \text { year }^{0.5}\right)\end{array}$} \\
& 180 days & 365 days & 180 days & 365 days & 180 days & 365 days & 0.5 year & 1 year \\
\hline CM & 420 & 580 & 5.9 & 6.24 & 1.21 & 2.64 & 1.711 & 2.640 \\
FS 10\% & 468 & 598 & 6.2 & 6.85 & 1.28 & 2.96 & 1.810 & 2.960 \\
FS 20\% & 516 & 654 & 6.9 & 7.64 & 2.01 & 3.18 & 2.843 & 3.180 \\
FS 30\% & 621 & 728 & 7.2 & 8.12 & 3.12 & 3.71 & 4.412 & 3.710 \\
FS 40\% & 816 & 991 & 9.1 & 10.48 & 4.85 & 5.45 & 6.859 & 5.450 \\
FS 50\% & 1021 & 1218 & 11.8 & 13.18 & 6.2 & 8.41 & 8.768 \\
\hline
\end{tabular}

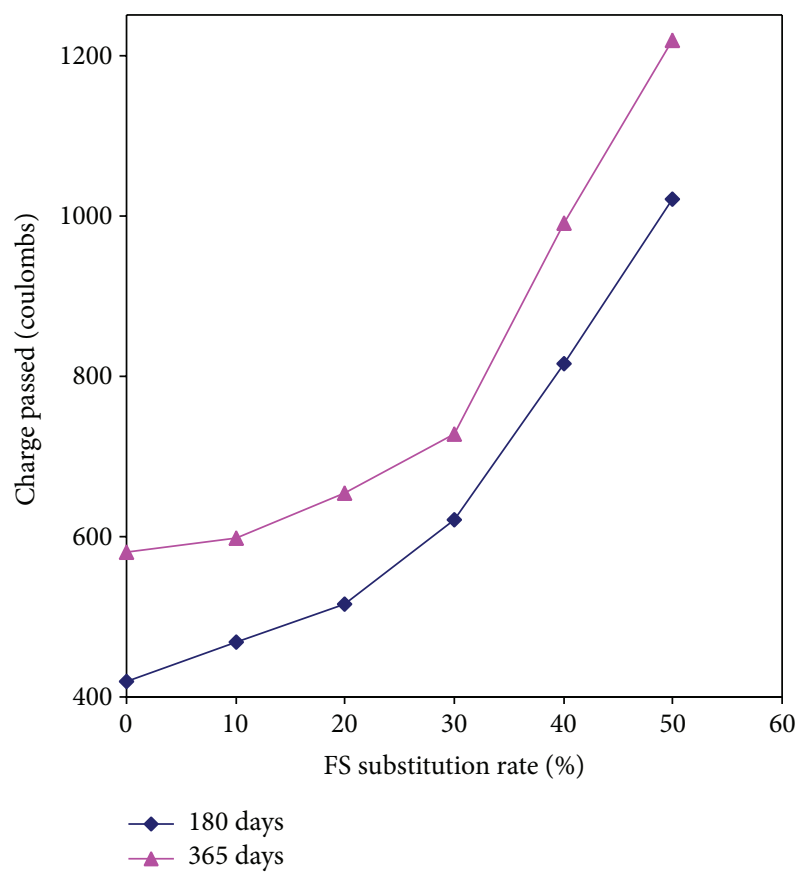

FIGURE 9: RCPT values of all mixtures at various ages: comparision.

in penetration value was observed at the age of 365 days. In general, the resistance to chloride penetration is higher, when the formation $\mathrm{C}_{3} \mathrm{~A}$ in the binder is higher. The FS used in this study contains $4.93 \%$ of $\mathrm{Al}_{2} \mathrm{O}_{3}$, which is relatively equal to the cement. Even though the presence of $\mathrm{SiO}_{2}$ and $\mathrm{Al}_{2} \mathrm{O}_{3}$ in the $\mathrm{FS}$ may form the denser tricalcium aluminates $\left(\mathrm{C}_{3} \mathrm{~A}\right)$, the poor workability of the concrete due to the fineness of FS, resulting in poor compaction of the concrete, led to a continuous porous microstructure. The other possible factor was that the presence of the wood and flour particles caused the formation of air voids in the concrete. In general, penetration has occurred along the water paths or open pores. The formation of this continuous pore system promoted the penetration of chloride ions. Mixtures FS 40\% and FS 50\% showed significantly higher chloride penetration compared to the CM. On the whole, the substitution of FS in concrete has a profound effect on the chloride penetration; however, this effect was not significant up to a substitution rate of 30\% and the penetration value was confirmed as being "very low" at both ages of concrete.

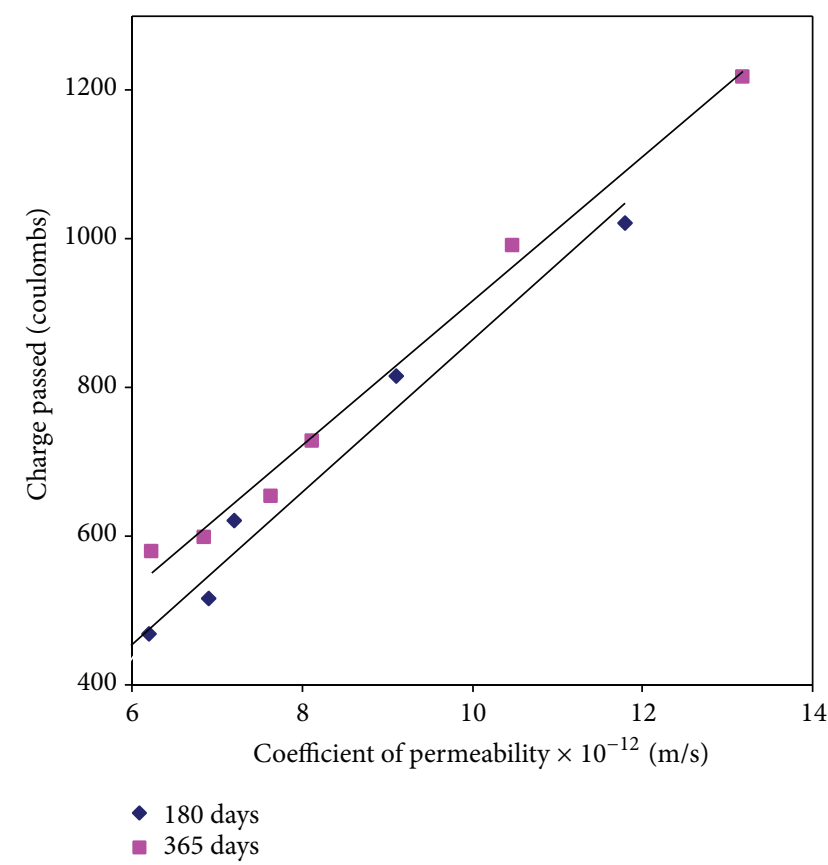

FIGURE 10: Relation between water permeability and RCPT values.

3.3.2. Water Permeability. According to the procedure described in IS:3085-1965 [31], the water permeability test was performed on all concrete mixtures at the age of 180 and 365 days. The test results obtained were presented in terms of permeability coefficient (see Table 5) by using (6) suggested in IS:3085-1965 [31]. Consider the following:

$$
K=\frac{Q}{A T \times(H / L)},
$$

where $Q$ and $A$ represent the quantity of water in millimeters and the area of the specimen face in $\mathrm{cm}^{2}$, respectively. $T$ and $H / L$ are the time in seconds and the ratio of the pressure head, respectively. Like RCPT, the results revealed that the permeability of the concrete increased when the substitution rate was increased; however, the influence was significant beyond the substitution rate of $30 \%$. The correlation between the water permeability and RCPT charges was shown to be quite strong, as can be seen in Figure 10. ACI 301-89 [11] recommended the maximum permeability coefficient value of $15 \times 10^{-12} \mathrm{~m} / \mathrm{s}$. The permeability coefficient value of $\mathrm{CM}$ 


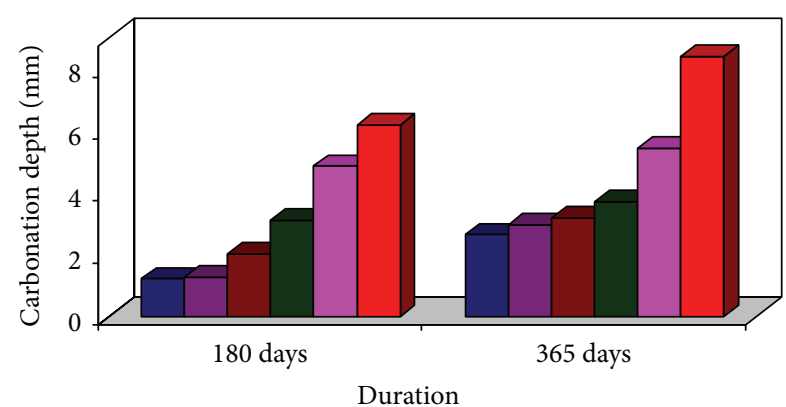

$\begin{array}{ll}\square \text { CM } & \square \text { FS } 30 \% \\ \square \text { FS } 10 \% & \square \text { FS } 40 \% \\ \square \text { FS } 20 \% & \square \text { FS } 50 \%\end{array}$

FIGURE 11: Cabonation depth values of all mixtures at various ages: comparision.

was about $5.9 \times 10^{-12} \mathrm{~m} / \mathrm{s}$ at the age of 180 days, whereas the FS $30 \%$ mixture showed a coefficient value of $7.2 \times 10^{-12} \mathrm{~m} / \mathrm{s}$, which is significantly lower than the maximum permeability coefficient value recommended in ACI 301-89 [11]. On the whole, the substitution of FS does not have a significant effect on water permeability up to a substitution rate of $30 \%$.

3.3.3. Carbonation Depth. Carbonation of concrete is one of the critical parameters associated with the corrosion of steel reinforcements. For all mixtures, carbonation depth was measured at the ages of 180 and 365 days and summarized in Table 5. The obtained results in terms of carbonation coefficient $(C)$ value using (7) [19] are presented in Figure 11. To compare the carbonation resistance, (7) is generally used, suggested by many researchers [19]. Consider the following:

$$
C=\frac{X}{T^{0.5}}
$$

where $C$ is the carbonation coefficient $\left(\mathrm{mm} /\right.$ year $\left.^{0.5}\right)$, and $X$ and $T$ are the carbonation depth in $\mathrm{mm}$ and period of exposure in years, respectively. The results demonstrated that the carbonation depth of the concrete increases with the increased substitution rate; in addition, the increase in depth was significant beyond the substitution rate of $30 \%$. Compared to mixture FS $30 \%$, control mixture has shown their resistance to carbonation by only $38.89 \%$, higher, which is not relatively high, and the difference is acceptable. Similar behaviour was observed by Siddique et al., 2011 [19]. Close observation of Figure 11 shows that the increase in carbonation depth with reference to the increase in the FS substitution rate was not linear. For the substitution rate of $20 \%$, the increase in carbonation depth value was $0.96 \mathrm{~mm}$ with reference to FS 10\%; however, for the substitution rate of $40 \%$, the increase in carbonation depth value was $1.73 \mathrm{~mm}$ with reference to FS $30 \%$. The increase in carbonation depth when the FS substitution rate is increasing can be attributed to the poor workability of the concrete, which resulted in poor compactness and led to the continuous porous system. The other reason is the presence of the carbon content in

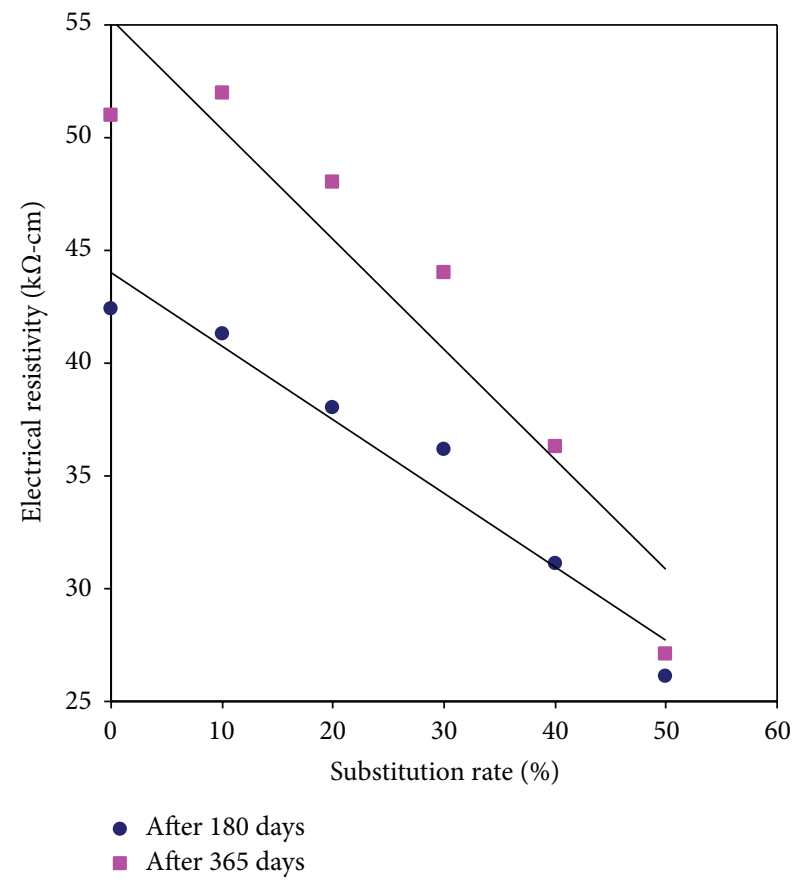

FIGURE 12: Electrical resistivity values of all mixtures at various ages: comparision.

the FS. Usually, carbon does not react with water under normal conditions. But under more forcing conditions, it may react with the water and produce $\mathrm{CO}$, and this reacts with calcium from calcium hydroxide and calcium silicate hydrate to form calcite $\left(\mathrm{CaCO}_{3}\right)$. From Figure 11, it can be understood that the increase in carbonation depth was proportional to the age of the concrete. The carbonation depth value of mixtures FS $40 \%$ and FS $50 \%$ were $5.45 \mathrm{~mm}$ and $8.41 \mathrm{~mm}$, respectively, at the age of 365 days, which was closer to the cover of reinforcing steel bars and may cause corrosion. From the above observation, it was concluded that concrete with a substitution rate of up to $30 \%$ can be considered as a good concrete, since the carbonation coefficient was never exceeded the value of $6 \mathrm{~mm} /$ month $^{0.5}$ [36] (see Table 5). However, concrete with a substitution rate beyond $30 \%$ is not advisable for structural concrete, since the carbonation depth value of mixtures was closer to the cover of reinforcing steel bars.

3.3.4. Electrical Resistivity Test. The electrical resistivity test is one of the methods used to evaluate the durability properties of the concrete, and the resistivity provided by the concrete is directly proportional to the density and pore structures of the concrete. The electrical resistivity provided by all concrete mixtures was measured at the ages of 180 and 365 days and are presented in Figure 12. Limeira et al. and Chao-Lung et al. [11, 37] suggested that the minimum electrical resistivity value beyond which corrosion that cannot occur is $20 \mathrm{k} \Omega$ $\mathrm{cm}$. The obtained results revealed that the resistivity value of the concrete mixtures with a substitution rate of up to $30 \%$ 


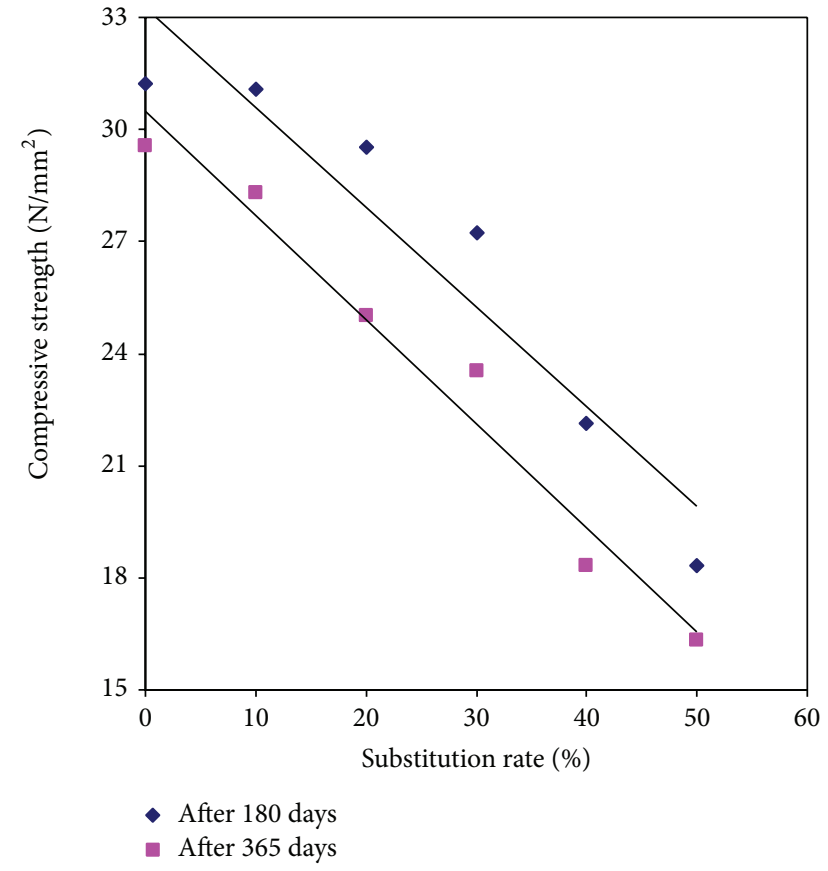

FIGURE 13: Sulphate resistance values of all mixtures at various ages: comparision.

were beyond $20 \mathrm{k} \Omega-\mathrm{cm}$ in all ages, while the resistivity value of the concrete mixtures decreased with the increase in the FS rate, as shown in Figure 12. The CM showed an electrical resistivity by only $10.37 \%$ and $14.62 \%$ higher when compared to the FS 20\% and FS 30\% mixtures, respectively, at the age of 180 days. As discussed above, this is a result of the fact that the poor workability of the concrete due to the fineness of the FS. The poor workability of the concrete decreases the effective compaction of the concrete, leading to continuous pore structures. It is concluded that the effect of FS with the substitution rate of up to $30 \%$ has superficial effects on the resistivity properties, but the influence was profound beyond the substitution rate of $30 \%$.

3.3.5. Sulphate Resistance. The sulphate resistance of the concrete was tested at the age of 180 and 365 days, and the results are presented in Figure 13. The test results revealed that the presence of FS decreases the sulphate resistance of the concrete, and this effect was further increased when the substitution rate was increased. At the ages of 180 and 365 days, the CM showed $6.18 \%$ and $13.41 \%$ decrease in compressive strength, respectively, due to sulphate attack. However, the mixtures containing FS showed a high reduction in compressive strength, and the effects were significant beyond the substitution rate of $30 \%$. The decrease in sulphate resistance FS concrete is due to the presence of traces of sulphur in the FS. The presence of $\mathrm{SO}_{3}$ may increase the strength of the $\mathrm{NaSO}_{4}$ and $\mathrm{MgSO}_{4}$ solution and enhances the ettringite formation $\left(\mathrm{Ca}_{6}\left(\mathrm{Al}(\mathrm{OH})_{6}\right)_{2}\left(\mathrm{SO}_{4}\right)_{3}\left(\mathrm{H}_{2} \mathrm{O}\right)_{25.7}\right)$, causing the deterioration of concrete. From the above observation, it can be concluded that the presence of reactive material in FS affects the durability properties of the concrete.

\section{Conclusion}

The reuse of FS as a substitute for natural sand in concrete production was evaluated based on the mechanical and durability properties of the resulting concrete. Based on the extensive tests carried out on the six mixtures, the following conclusion has been made.

(i) The chemical analysis of FS indicated that FS can be a very suitable material for concrete production. However, the fineness and high water absorption of FS increases the water demand of the concrete by water absorption, decreasing the workability of the concrete, although the effect was profound beyond the substitution rate of $30 \%$.

(ii) In all ages of concrete, the mechanical properties of concrete mixtures containing FS up to $30 \%$ was relatively equal to the strength value of the $\mathrm{CM}$. Compared to the mixture with FS 30\%, the CM had showed its mechanical properties by $6.3 \%$ higher on average.

(iii) The chloride penetration value of the $\mathrm{CM}$ was 420 coulombs, whereas the mixture FS $30 \%$ achieved the value of 621 coulombs at the age of 180 days, which is much less than the maximum value recommended in ASTM C1202-97.

(iv) Since the carbonation coefficient of the concrete mixture with a substitution rate of up to $30 \%$ was never exceeded the value of $6 \mathrm{~mm} / \mathrm{month}^{0.5}$, it can be considered as a good concrete.

(v) The CM increased electrical resistivity by only $10.37 \%$ and $14.62 \%$, respectively, when compared to the FS $20 \%$ and FS 30\% mixtures, at the age of 180 days.

(vi) The presence of sulphur traces in the FS increased the strength of the $\mathrm{NaSO}_{4}$ and $\mathrm{MgSO}_{4}$ solution and enhanced the ettringite formation, causing the deterioration of concrete.

(vii) It is recommended that the FS with a substitution rate up to $30 \%$ is favorable for the concrete production without adversely affecting the strength and durability criteria.

\section{Conflict of Interests}

The authors declare that there is no conflict of interests regarding the publication of this paper.

\section{Acknowledgment}

This research was supported by Basic Science Research Program through the National Research Foundation of Korea (NRF) funded by the Ministry of Science, ICT \& Future Planning (no. 2015R1A5A1037548). 


\section{References}

[1] D. A. R. Dolage, M. G. S. Dias, and C. T. Ariyawansa, "Offshore sand as a fine aggregate for concrete production," British Journal of Applied Science \& Technology, vol. 3, no. 4, pp. 813-825, 2013.

[2] T. Flexikala and P. Partheepan, "Granite powder concrete," Indian Journal of Science and Technology, vol. 3, pp. 311-317, 2010.

[3] H. Hebhoub, H. Aoun, M. Belachia, H. Houari, and E. Ghorbel, "Use of waste marble aggregates in concrete," Construction and Building Materials, vol. 25, no. 3, pp. 1167-1171, 2011.

[4] H. Binici, T. Shah, O. Aksogan, and H. Kaplan, "Durability of concrete made with granite and marble as recycle aggregates," Journal of Materials Processing Technology, vol. 208, no. 1-3, pp. 299-308, 2008.

[5] I. B. Topçu, T. Bilir, and T. Uygunoǧlu, "Effect of waste marble dust content as filler on properties of self-compacting concrete," Construction and Building Materials, vol. 23, no. 5, pp. 19471953, 2009.

[6] M. Vijayalakshmi, A. S. S. Sekar, and G. Ganesh Prabhu, "Strength and durability properties of concrete made with granite industry waste," Construction and Building Materials, vol. 46, pp. 1-7, 2013.

[7] M. Uysal, K. Yilmaz, and M. Ipek, "The effect of mineral admixtures on mechanical properties, chloride ion permeability and impermeability of self-compacting concrete," Construction and Building Materials, vol. 27, no. 1, pp. 263-270, 2012.

[8] A. Yilmaz and N. Degirmenci, "Possibility of using waste tire rubber and fly ash with Portland cement as construction materials," Waste Management, vol. 29, no. 5, pp. 1541-1546, 2009.

[9] W. Tangchirapat, T. Saeting, C. Jaturapitakkul, K. Kiattikomol, and A. Siripanichgorn, "Use of waste ash from palm oil industry in concrete," Waste Management, vol. 27, pp. 81-88, 2007.

[10] A. U. Elinwa and Y. A. Mahmood, "Ash from timber waste as cement replacement material," Cement \& Concrete Composites, vol. 24, no. 2, pp. 219-222, 2002.

[11] J. Limeira, M. Etxeberria, L. Agulló, and D. Molina, "Mechanical and durability properties of concrete made with dredged marine sand," Construction and Building Materials, vol. 25, no. 11, pp. 4165-4174, 2011.

[12] R. Siddique and A. Noumowe, "Utilization of spent foundry sand in controlled low-strength materials and concrete," Resources, Conservation and Recycling, vol. 53, no. 1-2, pp. 27-35, 2008.

[13] R. Siddique, G. D. Schutter, and A. Noumowe, "Effect of usedfoundry sand on the mechanical properties of concrete," Construction and Building Materials, vol. 23, no. 2, pp. 976-980, 2009.

[14] L. H. M. Vefago and J. Avellaneda, "Recycling concepts and the index of recyclability for building materials," Resources, Conservation and Recycling, vol. 72, pp. 127-135, 2013.

[15] S. Javed and C. W. Lovell, "Use of waste foundry sand in civil engineering," Transport Research Record 1486, Transportation Research Board, Washington, DC, USA, 1994.

[16] B. S. Q. Alves, R. S. Dungan, R. L. P. Carnin, R. Galvez, and C. R. S. de Carvalho Pinto, "Metals in waste foundry sands and an evaluation of their leaching and transport to groundwater," Water, Air, and Soil Pollution, vol. 225, no. 5, article 1963, 2014.
[17] R. Bakis, H. Koyuncu, and A. Demirbas, "An investigation of waste foundry sand in asphalt concrete mixtures," Waste Management and Research, vol. 24, no. 3, pp. 269-274, 2006.

[18] R. N. Kraus, T. R. Naik, B. W. Ramme, and R. Kumar, "Use of foundry silica-dust in manufacturing economical self-consolidating concrete," Construction and Building Materials, vol. 23, no. 11, pp. 3439-3442, 2009.

[19] R. Siddique, Y. Aggarwal, P. Aggarwal, E.-H. Kadri, and R. Bennacer, "Strength, durability, and micro-structural properties of concrete made with used-foundry sand (UFS)," Construction and Building Materials, vol. 25, no. 4, pp. 1916-1925, 2011.

[20] G. Singh and R. Siddique, "Abrasion resistance and strength properties of concrete containing waste foundry sand (WFS)," Construction and Building Materials, vol. 28, no. 1, pp. 421-426, 2012.

[21] H. M. Basar and N. D. Aksoy, "The effect of waste foundry sand (WFS) as partial replacement of sand on the mechanical, leaching and micro-structural characteristics of ready-mixed concrete," Construction and Building Materials, vol. 35, pp. 508$515,2012$.

[22] IS 8112:2013. Ordinary Portland Cement, 43 Grade-Specification, Bureau of Indian Standards, New Delhi, India, 2013.

[23] Bureau of Indian Standards, "Method of chemical analysis of hydraulic cement," IS 4032:1985, Bureau of Indian Standards, New Delhi, India, 1985.

[24] Bureau of Indian Standards, "Methods of test for aggregates for concrete: part 3 specific gravity, density, voids, absorption and bulking," Tech. Rep. IS 2386 (part 3), Bureau of Indian Standards, New Delhi, India, 1963.

[25] Bureau of Indian Standards, "Methods of test for aggregates for concrete: part 1-particle size and shape," IS 2386(Part 1), Bureau of Indian Standards, New Delhi, India, 1963.

[26] Bureau of Indian Standards, "Methods of test for determination of water absorption, apparent specific gravity and porosity of natural building stones," IS 1124:1974, Bureau of Indian Standards, New Delhi, India, 1974.

[27] IS 10262:2009, Guidelines for Concrete Mix Proportioning, Bureau of Indian Standards, New Delhi, India, 2009.

[28] G. G. Prabhu, J. H. Hyun, and Y. Y. Kim, "Effects of foundry sand as a fine aggregate in concrete production," Construction and Building Materials, vol. 70, pp. 514-521, 2014.

[29] Bureau of Indian Standards, "Methods of tests for strength of concrete," Tech. Rep. IS: 516-1959, Bureau of Indian Standards, New Delhi, India, 1959.

[30] ASTM, "Standard test method for electrical indication of concrete's ability to resist chloride ion penetration," ASTM C120297, ASTM International, Conshohocken, Pa, USA, 1997.

[31] Bureau of Indian Standards, "Method of test for permeability of cement mortar and concrete," IS 3085:1965, Bureau of Indian Standards, New Delhi, India, 1965.

[32] ACI 209.2R-08, Guide for Modeling and Calculating Shrinkage and Creep in Hardened Concrete.

[33] Bureau of Indian Standards, "Plain and reinforced concrete code of practice," IS 456:2000, Bureau of Indian Standards, New Delhi, India, 2000.

[34] Comité Euro-International du Béton, CEB-FIP Model Code (1990). Design Code, Thomas Telford, 1993.

[35] IS 13311(Part 1):1992, Methods of Non-Destructive Testing of Concrete: Part 1 Ultrasonic Pulse Velocity, Bureau of Indian Standards, New Delhi, India, 1992. 
[36] P. Castroa, M. A. Sanjuan, and J. Ganesca, "Carbonation of concrete in Mexico Gulf," Building and Environment, vol. 35, pp. 145-149, 2000.

[37] H. Chao-Lung, B. L. Anh-Tuan, and C. Chun-Tsun, "Effect of rice husk ash on the strength and durability characteristics of concrete," Construction and Building Materials, vol. 25, no. 9, pp. 3768-3772, 2011. 

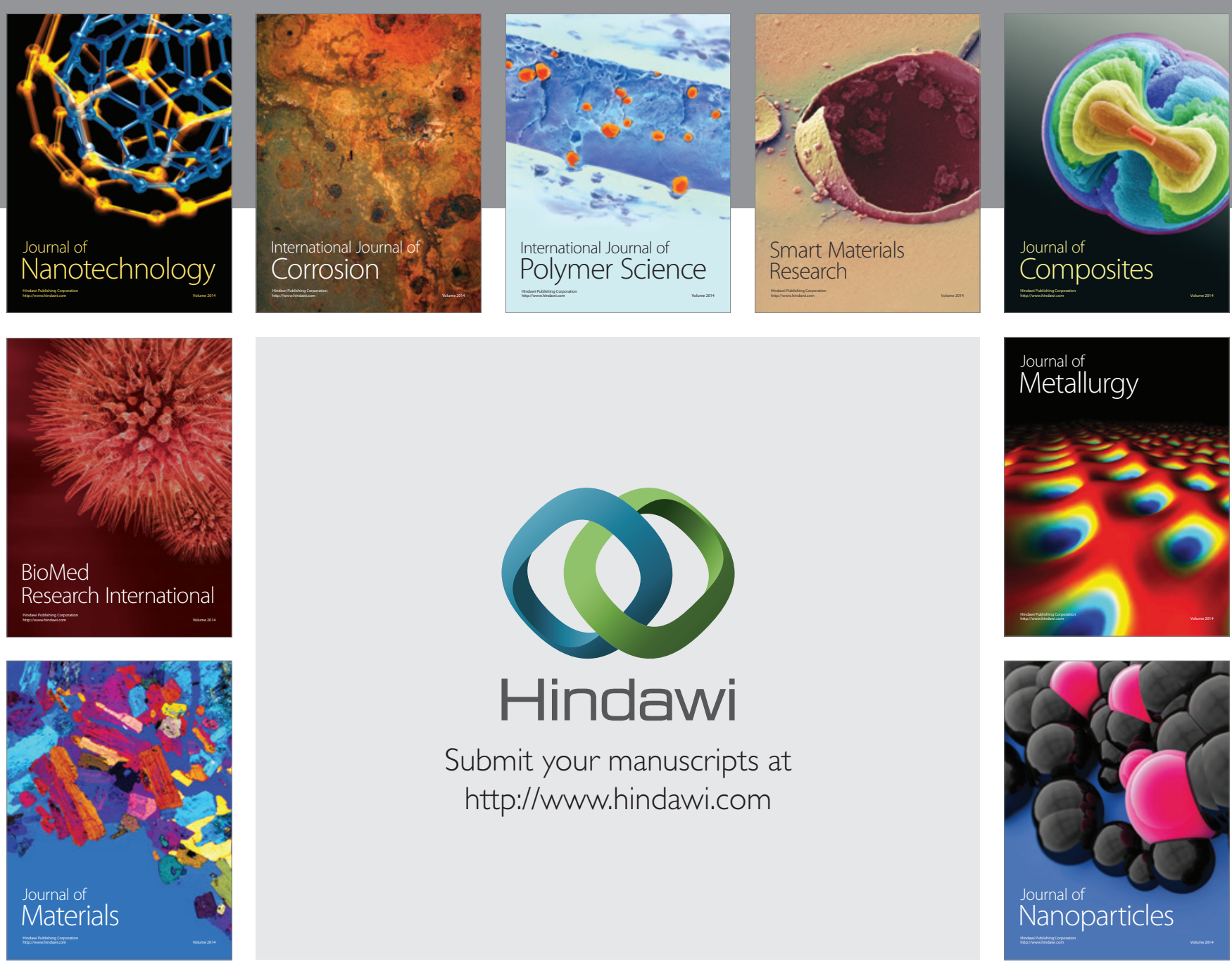

Submit your manuscripts at http://www.hindawi.com
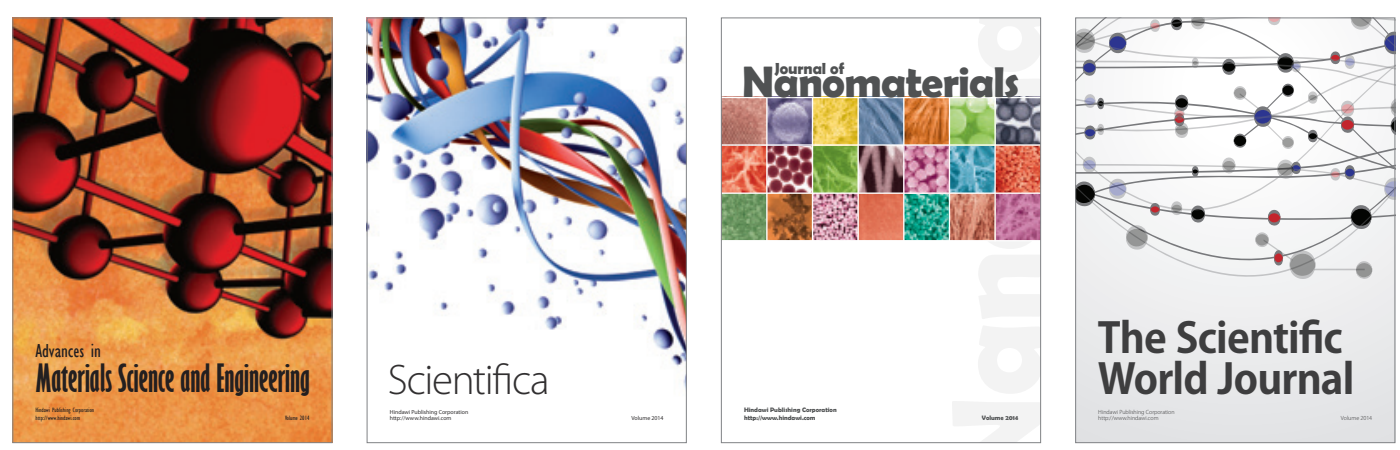

\section{The Scientific World Journal}
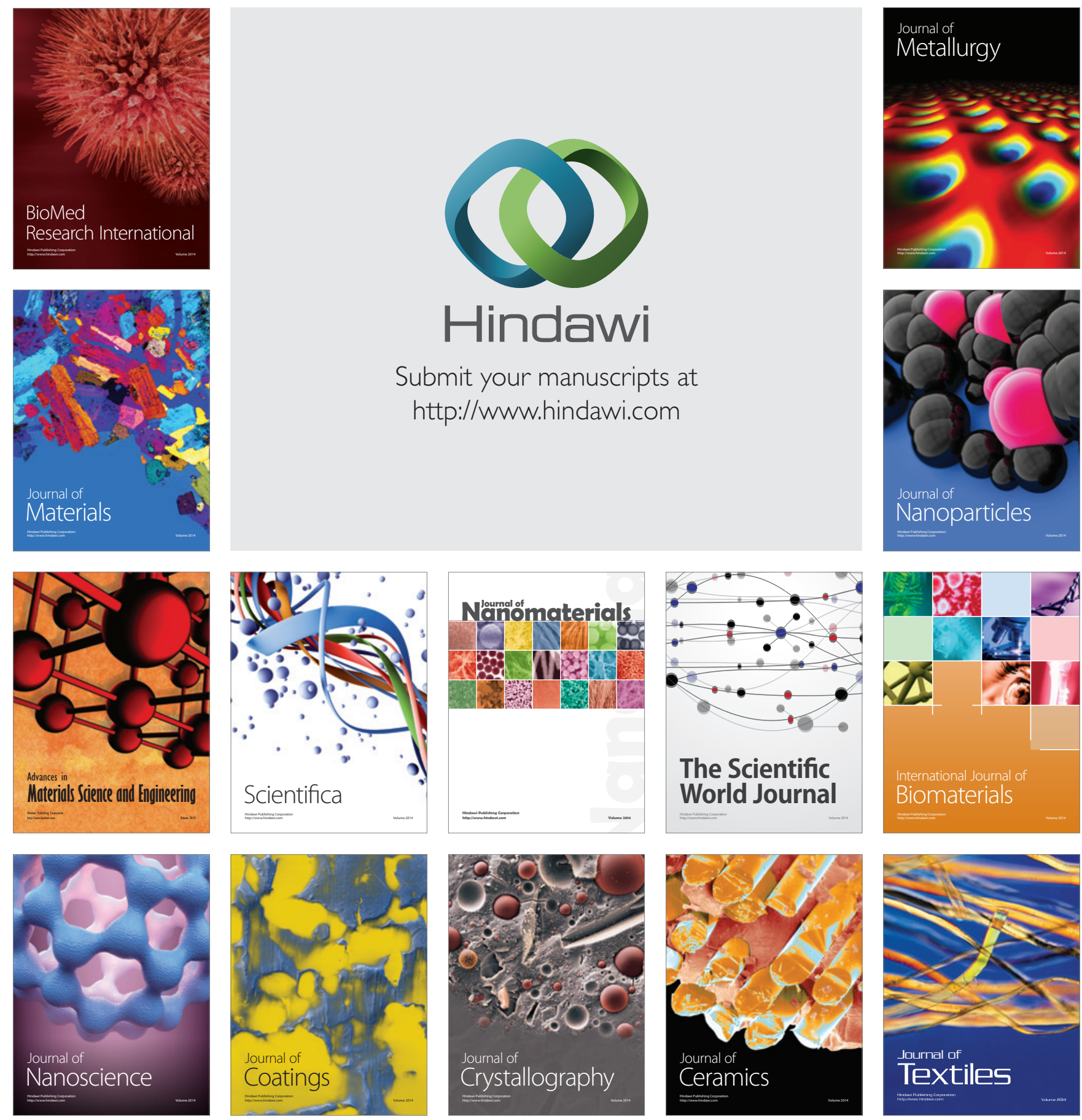